\title{
A Cultural Resources Survey for Medina Electric Cooperative, Inc., in Uvalde, Medina, and Frio Counties, Texas
}

Augustine Frkuska Jr.

Elizabeth G. Frkuska

Follow this and additional works at: https://scholarworks.sfasu.edu/ita

Part of the American Material Culture Commons, Archaeological Anthropology Commons, Environmental Studies Commons, Other American Studies Commons, Other Arts and Humanities Commons, Other History of Art, Architecture, and Archaeology Commons, and the United States History Commons

Tell us how this article helped you.

This Article is brought to you for free and open access by the Center for Regional Heritage Research at SFA ScholarWorks. It has been accepted for inclusion in Index of Texas Archaeology: Open Access Gray Literature from the Lone Star State by an authorized editor of SFA ScholarWorks. For more information, please contact cdsscholarworks@sfasu.edu. 


\section{A Cultural Resources Survey for Medina Electric Cooperative, Inc., in Uvalde,}

Medina, and Frio Counties, Texas

\section{Creative Commons License}

\section{(c) (1) \&}

This work is licensed under a Creative Commons Attribution-NonCommercial 4.0 International License 


\section{A CULTURAL RESOURCE SURVEY FOR MEDINA ELECTRIC COOPERATIVE, INC,, IN UVALDE, MEDINA, AND FRIO COUNTIES, TEXAS}

AUGUSTINE FRKUSKA, JR, AND ELIZABETH G, FRKUSKA

Center for Archaeological Research The University of Texas at San Antonio Archaeological Survey Report, No. 117 



\section{A CULTURAL RESOURCE SURVEY FOR}

MEDINA ELECTRIC COOPERATIVE, INC.,

IN UVALDE, MEDINA, AND FRIO COUNTIES,

TEXAS

Augustine Frkuska, Jr.

and

Elizabeth G. Frkuska

Center for Archaeological Research The University of Texas at San Antonio Archaeological Survey Report, No. 117 



\section{TABLE OF CONTENTS}

Page

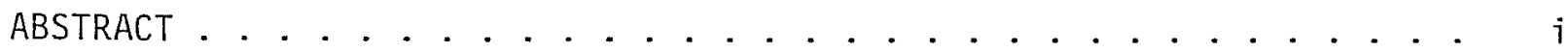

INTRODUCTION . . . . . . . . . . . . . . . . . . . . . . . . . . . . 1

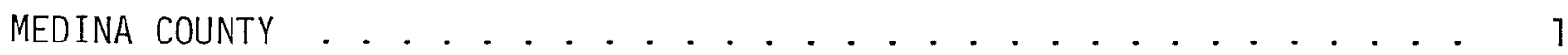

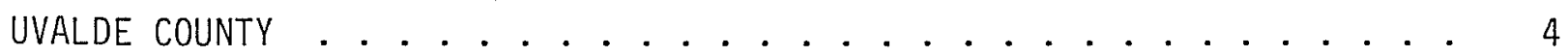

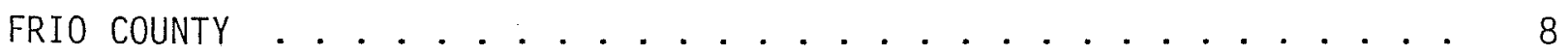

CONCLUSIONS AND RECOMMENDATION . . . . . . . . . . . . . . . . . . . . 13

ACKNOWLEDGMENTS . . . . . . . . . . . . . . . . . . . . . . . . 13

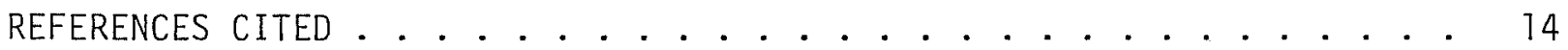

\section{LIST OF FIGURES}

Figure

1. Map of Texas Showing Areas of Survey in Their Respective Counties....................... . . . 2

2. Map Showing Surveyed Substation Site and Electrical Distribution Line Passing Through the D'Hanis Historic District . . . . . . . 5

3. Map Showing Survey Route of Substation Site and Electrical Distribution Line North of Uvalde, Texas . . . . . . . . . . 6

4. Map Showing the Location of the Derby Substation Site and Distribution Line Route Near Pearsal1, Texas . . . . . . . . . 10

5. Artifacts from $41 \mathrm{FR} 20$...................... 11

6. Artifacts from 41 FR 21 . . . . . . . . . . . . . . . . . . 12 

The Center for Archaeological Research (CAR), The University of Texas at San Antonio (UTSA), under contract with Alexander Utility Engineering, Inc., (letter dated May 5, 1980), conducted an archaeological survey for the Medina Electric Cooperative, Inc. A7though the CAR was contracted in May 1980, at the request of Medina Electric Cooperative, Inc., the actual survey was not carried out unti1 February 25-March 1, 1981. The survey, which was conducted in three neighboring south Texas counties (Fig. 1), was concentrated along proposed electrical distribution Tines at D'Hanis in Medina County, north of Uvalde in Uvalde County, and southwest of Pearsall in Frio County. General supervision of the project was provided by Dr. Thomas R. Hester, Director, and Jack D. Eaton, Associate Director, of the CAR-UTSA. The project was carried out by Augustine and Elizabeth Frkuska, Center staff archaeologists.

The survey methods were based upon the guidelines for site survey presented in Field Methods in Archaeology (Hester, Heizer, and Graham 1975:13-36). Any artifacts observed along the proposed routes were recorded as to their location and association with their environment. The areas surveyed were restricted in width since the majority of the proposed distribution lines followed public road rightof-ways, including areas just inside private property fronting along the road. Holes are to be excavated at predetermined intervals to set the utility poles, and in certain areas along the route there are to be anchor pins for the distribution lines. In addition, electrical system substations are to be constructed. This would involve the landscaping and fencing of designated areas along each of the proposed lines.

All field information was recorded on standard forms. Photographs were taken of distribution line routes and potential sites. Selected artifacts were collected from the surface of sites and stored in paper bags labeled with a temporary site number. The site was then located and marked on a 7.5' United States Geological Survey (USGS) topographic map. All artifacts and collected data were processed according to standard archaeological procedures. Interpretations presented in this report are based on information obtained from the field survey and literature research. The information is presented under the names given to the distribution line routes and substations by the Medina Electric Cooperative, Inc.

The areas surveyed for the Medina Electric Cooperative, Inc., are encompassed by the south-central Texas region. Five major chronological periods are recognized for this area of Texas. These periods are: (1) Paleo-Indian (ca. 9200 B.C.6000 B.C.), (2) Pre-Archaic (ca. 6000 B.C.-3500 B.C.), (3) Archaic (ca. 3500 B.C.A.D. 1000), (4) Late Prehistoric (ca. A.D. 1000-Historic contact), and (5) Historic (the period of historic European intrusion). The prehistoric occupation in south-central Texas is represented by all chronological periods. The sections describing the previous archaeology for each of the surveyed areas refer to this chronology.

\section{MEDINA COUNTY}

\section{Environment}

Medina County is located south of the edge of the Great Plains Province and in the northern portion of the West Gulf Coastal Plain (Hunt 1967:159). The 


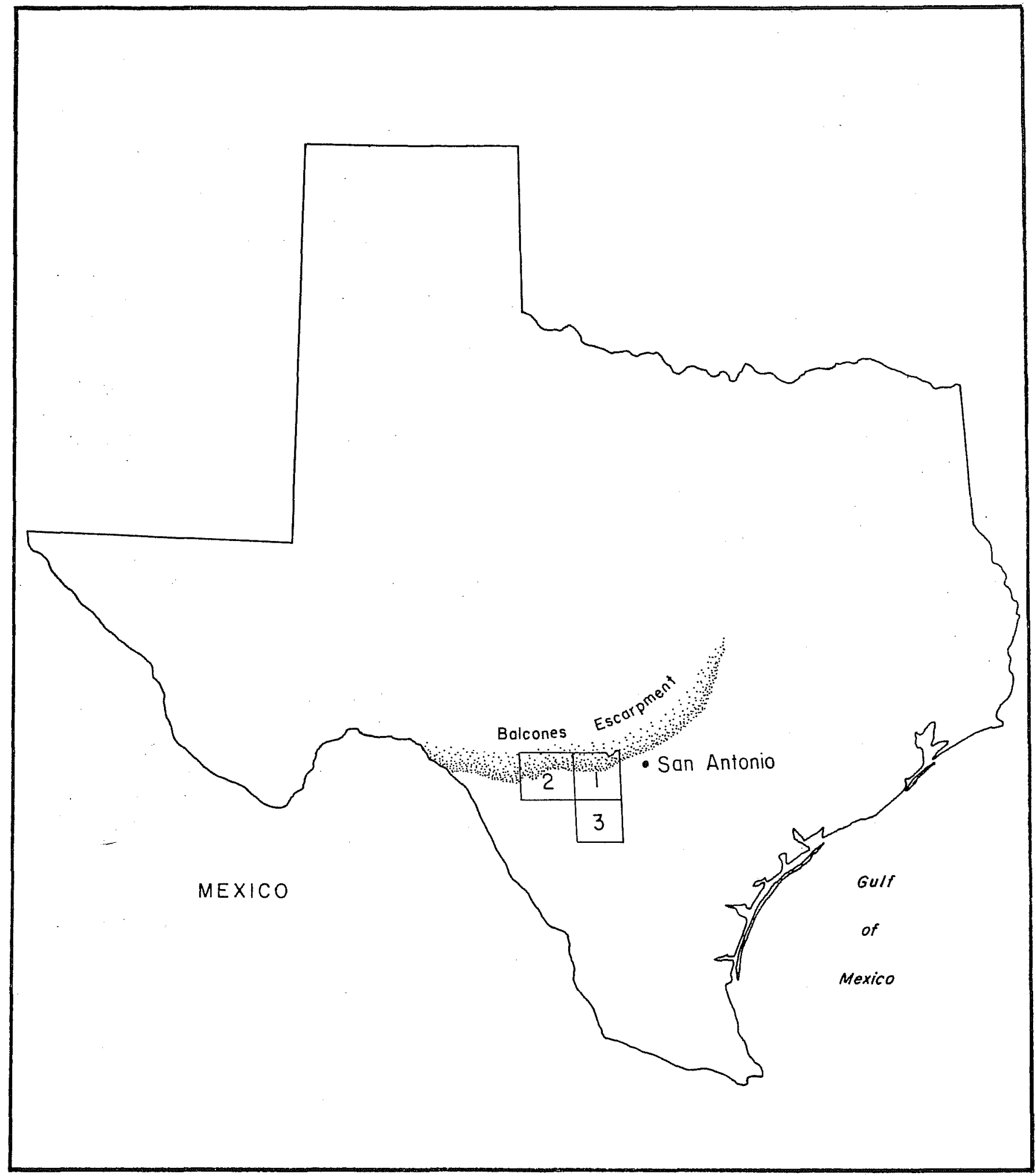

Figure 1. Map of Texas Showing Areas of Survey in Their Respective Counties. 1, Medina County, D'Hanis substation; 2, Uvalde County, Ferris substation; 3, Frio County, Derby substation. 
elevation of Medina County may vary by 1500 feet, from the northern portion upon the Edwards Plateau to the southern portion well onto the Coastal Plain. The county lies within the Tamaulipan and Balconian biotic provinces (Blair 1950). The soils are a Rio Grande Plain Upland type consisting of hard to neutral calcareous clays and clay loams. Also found along with the clay loam is a grayish brown to neutral sandy loam (Ellis, Jordan, and Buchanan 1976:34): Vegetation ranges from a mesquite-chaparral savanna in the southern portion to a juniperoak mesquite savanna in the northern portion (ibid.:33). The climate reflects the topography of the 1and. For example, the warm moist air from the Gulf ascends to cooler altitudes at the Balcones Escarpment and Edwards Plateau, releasing precipitation. This precipitation contributes to the total annual rainfall of 32 inches (Carr 1967:6-9). The availability of moisture in the region plays an important part in the utilization of the land by prehistoric and historic settlers. There are a few major river channels that carry water the majority of the year.

\section{Historical Background}

The Medina River is the main water drainage system in Medina County. Alonso de Leon crossed the area and named the river in 1689. By 1718, the river was recognized as the western boundary of Texas, which at a later date was pushed back to the Nueces River (Webb 1952 Vol. 1:169). Parts of Medina, Uvalde, and Frio Counties came under land granted to Henri Castro, a German, for colonization purposes. In 1844, Henri Castro left San Antonio to colonize what is known as Castroville. The Castroville area, now registered as the Castroville Historic District, contains the historic Landmark Inn Complex which was excavated by the Texas Historical Commission (Hester 1975a). Castro set up a number of towns west of Castroville. In 1847, Castro founded the town of D'Hanis some 25 miles west of Castroville (Haass 1908:80). In 1881, the Galveston, Harrisburgh, and San Antonio Railroad was built north of town. This caused the town to relocate to the present position. The 01d D'Hanis Historic District presently contains a few farms and family units. Scattered among the recent homes are remains of cut 7 imestone block houses and the shell of St. Dominic's Catholic Church. Outside the church lies a cemetery with markers of some of the original settlers. The first church was a log structure built in 1850. The cornerstone for the stone church was placed in 1868 (Finger 1972). North of D'Hanis, Fort Lincoln was established along the Seco River to protect the settlements in the area; however, the fort was abandoned in 1851 (ibid.). Today, a few farms and ranches in the area are registered in the Texas Family Land Heritage Registry (e.g., Rothe Charolais Ranch, 1972, and Quihi Soathoffs Farm, 1846).

\section{Previous Archaeology}

The majority of the prehistoric sites recorded in Medina County are located in the northern portion of the county. Patterson (1975) recorded a few sites and reported on an important quarry site (41 MC 3). Whitsett (1976) provided the Texas Water Quality Board with an archaeological reconnaissance near Natalia. In 1976, the Center for. Archaeological Research investigated the sites found earlier by Whitsett (Hester and Kel7y 1976:14). Chadderdon in 1977 recorded the Leippe site, 41 ME 25 (notes on file, CAR-UTSA). Scorpion Cave (41 ME 7) 
was excavated in 1971 and the results published in 1978 (Highley et al. 1978: 139-194). The wealth of data collected from this site alone leads to a better understanding of how prehistoric cultures utilized the area. Because of the small amount of scientific archaeological work that has been done in the area, it is certain that many other prehistoric sites lie undiscovered or unreported in Medina County.

The sites excavated and those sites that have been recorded have given archaeologists an idea of the prehistoric chronology of the area. 0ccupation of Scorpion Cave (4l ME 7) is well represented from the Pre-Archaic to the Late Prehistoric.

\section{Field Investigations}

The proposed D'Hanis distribution line route will be constructed through the 01d D'Hanis Historic District. Approximately two miles of new line will be built to connect the new D'Hanis substation, which lies west of the historic district, to an existing feeder network north of the district (Fig. 2). The proposed line was to follow an asphalt-paved road. The supporting utility poles were to occupy private property, of which $40 \%$ is presently under cultivation. Particular care was taken in this survey to locate any possible historic debris of construction remains. No historic or prehistoric cultural evidence was found in the affected area. Therefore, the placing of the utility poles would not disturb any known cultural deposits in the historic zone of old D'Hanis.

\section{UVALDE COUNTY}

\section{Environment}

The town of Uvalde is located just south of the Great Plains Province and in the northwestern portion of the West Gulf Plain (Hunt 1967:9). Most of the area is within the Tamaulipan Biotic Province of south Texas, al though the northern portion lies in the Balconian province (BTair 1950). The elevation greatly differs as one approaches the Balcones Escarpment to the Edwards Plateau to the north. The Uvalde terrain has sloping to undulating hills with shallow, stony, and gravelly loam soils (Stevens and Richmond 1976:4). Sporadically, throughout the Uvalde area, an intrusion of magma into the Cretaceous upper layer can be seen. Black mountain, illustrated in Figure 3 , is such an intrusion. The igneous rock, or traprock, is highly erosion resistant and is commercially quarried near Knippa.

The climate is much like that in Medina County to the east. The rainfall is less because the county is affected more by the dry continental air from the Great Basin high-pressure cell (Barry and Chorley 1968:158). The rainfall for the most part is less than 28 inches a year, though at times it may exceed 35 inches or total less than 13.6 inches a year (Carr 1967:6). The area is in the Edwards Plateau climatic region, with hot humid summers and dry winters (ibid.).

The vegetation is much like Medina County, with mesquite savanna and an oakjuniper woodland to the north and a chaparral savanna to the south (E17is, Jordan, and Buchanan 1976). The Uvalde area is on the Balcones fault zone. 


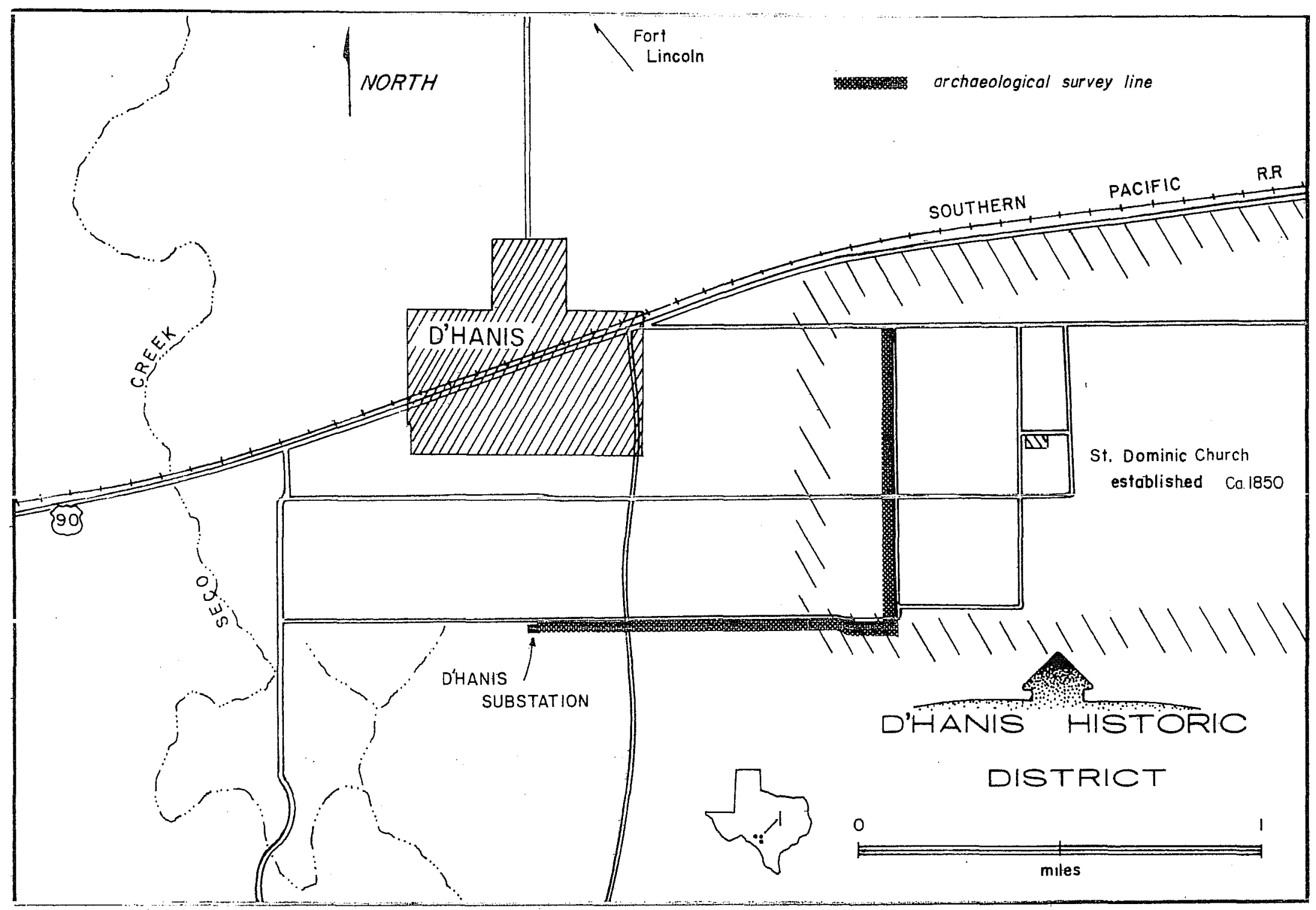

Figure 2. Map Showing Surveyed Substation Site and Electrical Distribution Line Passing Through the D'Hanis Historic District. 


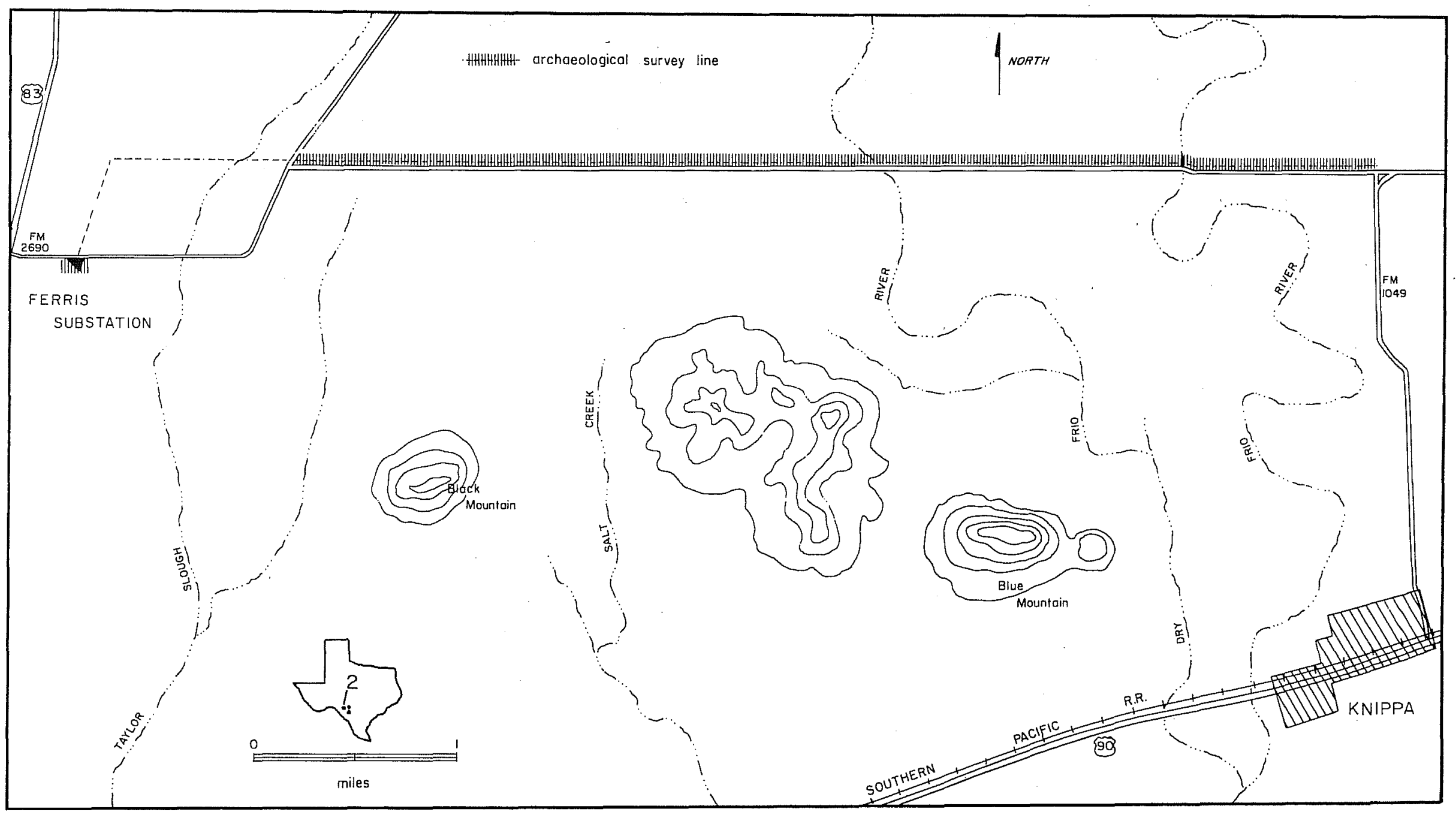

Figure 3. Map Showing Survey Route of Substation Site and Electrical Distribution Line North of Uvalde, Texas. 
This zone is known to contain springs fed by the Edwards-Trinity and Edwards Aquifers (Brune 1975:12). The location of these waterholes was known throughout the prehistoric area. Historically, places such as Soldiers Camp Springs and the Leona Springs group near Uvalde were heavily used (ibid.:75).

\section{Historical Background}

In the late 1600s, Alonso de Leon traveled north of the Rio Grande to name the Nueces River. By 1762, two missions, Mission San Lorenzo de la Santa Cruz and Nuestra Señor de Candelaria de Canon, were set up to christianize marauding Lipan Apache and Comanche Indians (Tunnell and Newcomb 1969). The missions, operating under constant desertion and hostile Indian attacks, were soon abandoned. Fort Inge was established in 1849 as one in a series of forts established along the 01d San Antonio Road from San Antonio to Fort Duncan and El Paso (Webb 1952 Vol. 1:827). A settlement called Encina was established near Fort Inge. The name of the town was changed to Uvalde. Uvalde later became an important shipping depot for train transportation in the last quarter of the 19th century. Structures in the town of Uvalde which are registered in the National Register of Historic Places include the Grand Opera House, John Nance Garner House, and the Ettie R. Garner Memorial Museum.

\section{Previous Archaeology}

Hunting and gathering nomadic Indians utilized the Uvalde area for over 10,000 years. The chronology of the area generally follows the previous chronology for south Texas. The cultural periods proposed in the Uvalde area are typified by the data collected from the La Jita site, excavated by Thomas R. Hester (1971). The Mason Ranch Burial Cave northwest of Uvalde was reported by Benfer and Benfer (1981). In the 1ate 1940s, the Montell Rockshelter and Kincaid Shelter excavations revealed Paleo-Indian and Archaic materials. Recently, the Leona River Project recorded campsites, middens, hearths, and lithic concentrations in the area around the Leona River drainage (Hal1 1974; P. Lukoswki, personal communication). The Texas Highway Department archaeologists tested two sites in Uvalde County located near Sabinal and Uvalde (Young 1979; Luke 1979). Present7y the Center for Archaeological Research is undertaking excavation of archaeological sites along the Leona River Watershed. The results of these investigations should yield a better understanding of Archaic and Late Prehistoric settlement patterns in the area ( $P$. Lukowski, personal communication). The Leona River and Taylor Slough drainages contain significant archaeological sites to be nominated to the National Register of Historic Places. The proposed distribution line and Ferris substation are located just north of these areas.

\section{Field Investigations}

The archaeological survey for the Ferris substation and distribution line covered approximately six miles, where utility poles will be erected along FM 2690 just inside the private property lines (Fig. 3). The distribution line is to cross three main drainages: Taylor Slough, Dry Frio River, and the Frio River. Particular attention was directed to the area near the watercourses. Concentrations 
of archaeological sites were found in near proximity to water in Taylor Slough and the Leona River. Whenever possible, natural cuts into the soil along the watercourses were examined for buried cultural remains. Cultivated fields along the route were also examined. No prehistoric or historic cultural remains were

observed. Therefore, further testing or other work is not recommended.

FRIO COUNTY

Environment

Rolling hills to nearly level plains typify the terrain for the study area of Frio County. Topographically, it lies in the Coastal Plain Province (Carr 1967: 3). The county Ties within the Tamaulipan Biotic Province (BTair 1950). The soils in the Coastal Plain are a dark calcareous clay loam to a slightly acidic to neutral sandy loam. Color of the soil ranges from a grayish brown to a reddish brown. The climate for Frio County is within the southern climatic division and averages approximately 22 inches of rain annually. The amount of moisture supports a mesquite-chaparral savanna with small trees, shrubs, cactus, and large areas of brush. A few large oak trees survive in a riparian zone. Although no major springs occur in Frio County, a few major drainages cross the county. These drainages are the Frio River and San Miguel Creek.

\section{Historical Background}

The history of Frio County appears to be that of a land with many open ranges and a few historic settlements, Martin de Alarcon, founder of San Antonio, took a course through the middle of the county in 1718 (Webb 1952 Vol. 1:649). The Canary Islanders passed through the county to establish a civitian government in San Antonio. In 1836, Antonio Lopez de Santa Anna and the Mexican Army stopped at the old crossing on the Frio River on their way to beseige the Alamo (ibid.). The land was widely used for ranching, and the railroad from Laredo to San Antonio encouraged settlement in the area. The railroad made new towns and caused old ones to be abandoned. 01d Frio Town, like 01d D'Hanis in Medina County, was moved and rebuilt along the railroad. Until the last 30 years, the area has seen little change. The push by the oil industry to tap the oil pool around the Pearsall area has led to a tremendous amount of land alteration. The land alteration has accelerated the rate of destruction or prehistoric cultural resources. These resources are vital in understanding the prehistoric population and should be taken into consideration upon development of the area.

\section{Previous Archaeology}

The archaeology of Frio County is very poorly known. A few artifacts found in the county are mentioned in early publications. In 1954, Dr. T. N. Campbel1's University of Texas class collected and recorded sites in Frio County. These investigations are reported in Hester (1968), who has described a number of Paleo-Indian artifacts recovered from the surface in Frio, Atascosa, and McMullen Counties along the San Miguel Creek. The sites in the county are, for the majority, Archaic by artifact assemblage. H. P. Smith, Jr. has recorded 
several sites just above the Leona River confluence. The description of the sites indicates that they are extensively eroded. The sites were located on the slopes among the gravel outcrops (CAR files). The eroding chert gravels were accessible resources for the production of prehistoric stone tools.

\section{Field Investigations}

The archaeological survey of the Derby line (south of Pearsall) and substation involved approximately seven miles of new feeders to be constructed to serve the general areas of Dilley and Pearsal1. The new distribution line is to proceed east from the Derby substation for a distance of approximately two miles along an unimproved road. The line will turn north along the north-south fenceline of private property owners. Along this particular fenceline there exists a buried gas line. At the north juncture with the Beevers Farm, the line will turn east and run along an east-west fenceline (Fig. 4).

The proposed line was surveyed on foot. Two areas of lithic concentrations were located on two eroded gravel shelves along the east slope of the Frio River. This geological occurrence is commercially quarried just north of the proposed distribution line.

The first lithic concentration (site 41 FR 20) was located midway down the slope among eroded gravels. The siliceous 1 imestone ranged in size from pebbles to cobbles. The dimensions of the site were $50 \mathrm{~m}$ north-south and $100 \mathrm{~m}$ east-west. The lithic material observed appeared to be limited to the surface. A representative sample was collected and taken back to the CAR laboratory for analysis. Among the artifacts noted were large primary and secondary cortex flakes. Unifacial and bifacial cores were also observed (Fig. 5). In addition, a large number of cobbles were broken, exposing the inner matrix of the rock.

The presence of primary and secondary flakes with the total number of cores and quarry blanks suggests quarrying activities. The majority of the flakes have large platforms and massive bulbs of percussion. This trait suggests a hard percussor was used to knock off the flakes. The absence of small worked tools or altered flaking debris suggests the selected quarried material was taken to another locality (perhaps to a small chipping station or base camp closer to a water source) where a more refined reduction sequence was used.

The second lithic concentration (site 41 FR 21) was located in an exposed gravel outcrop on the floodplain of the Frio River at the base of the slope (Fig. 4). The lithic concentration appears to be debris of more refined 1 ithic reduction activities. The majority of the flakes contained little cortex. A representative sample was collected and returned to the laboratory for analysis. The dimensions of the site measured $35 \mathrm{~m}$ north-south by $70 \mathrm{~m}$ east-west and were limited in depth to the surface. The 1 ithic assemblage consists of small bifacial preforms, tools, and small flakes (Fig. 6). A projectile point and a biface both appear to have been retouched, perhaps to perform a specific function. The projectile point is similar to the dart point type known as Gower (Wesolowsky, Hester, and Brown 1976:47). The Gower-type is associated with Paleo-Indian or Pre-Archaic assemblages (Hester 1979; Shafer 1979). 
This page has been

redacted because it

contains restricted

information. 


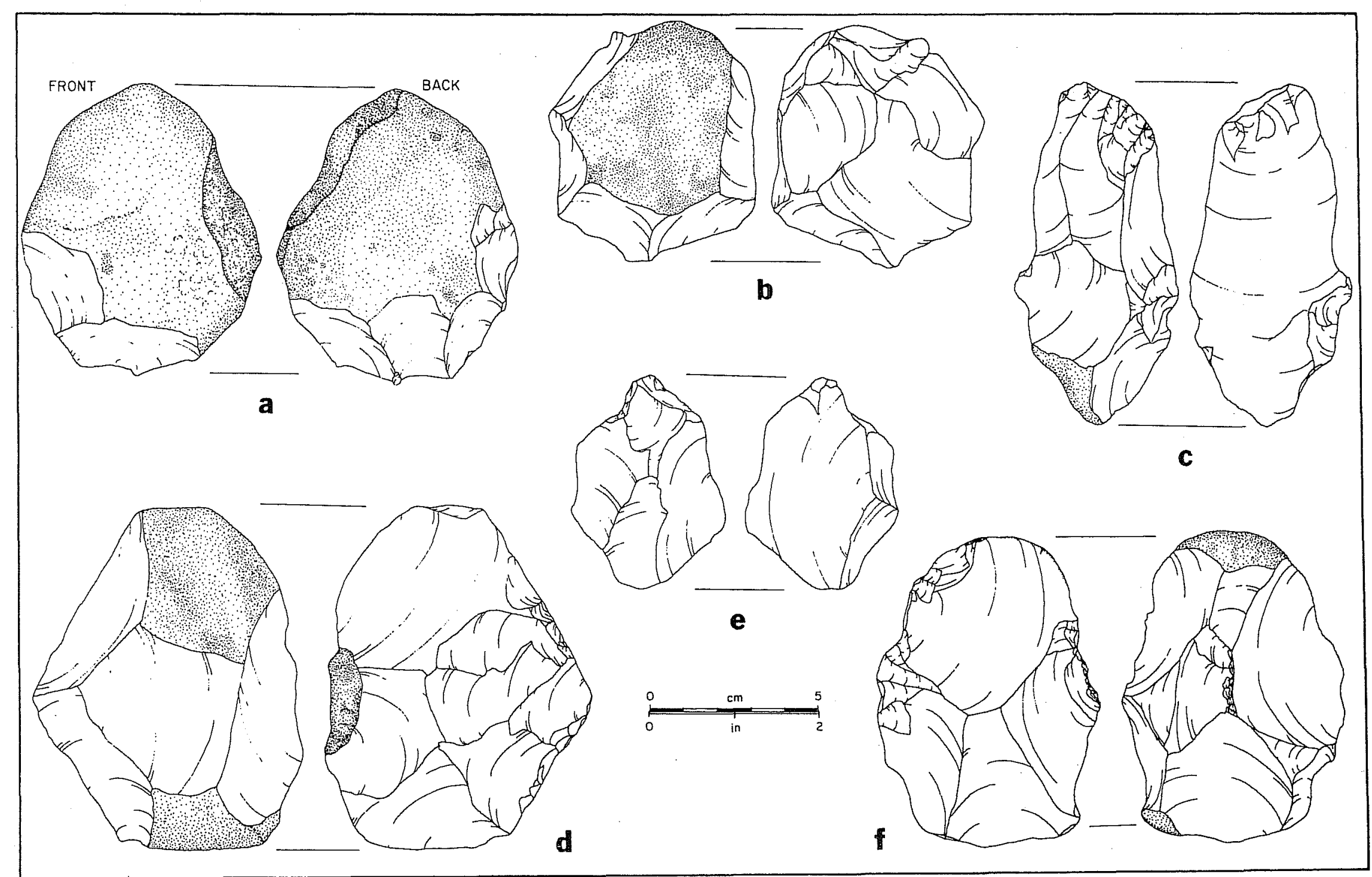

Figure 5. Artifacts from 41 FR 20. a,b,e,f, bifacial cores; c, secondary flake with prepared platform; d, bifacial thinning flake. 


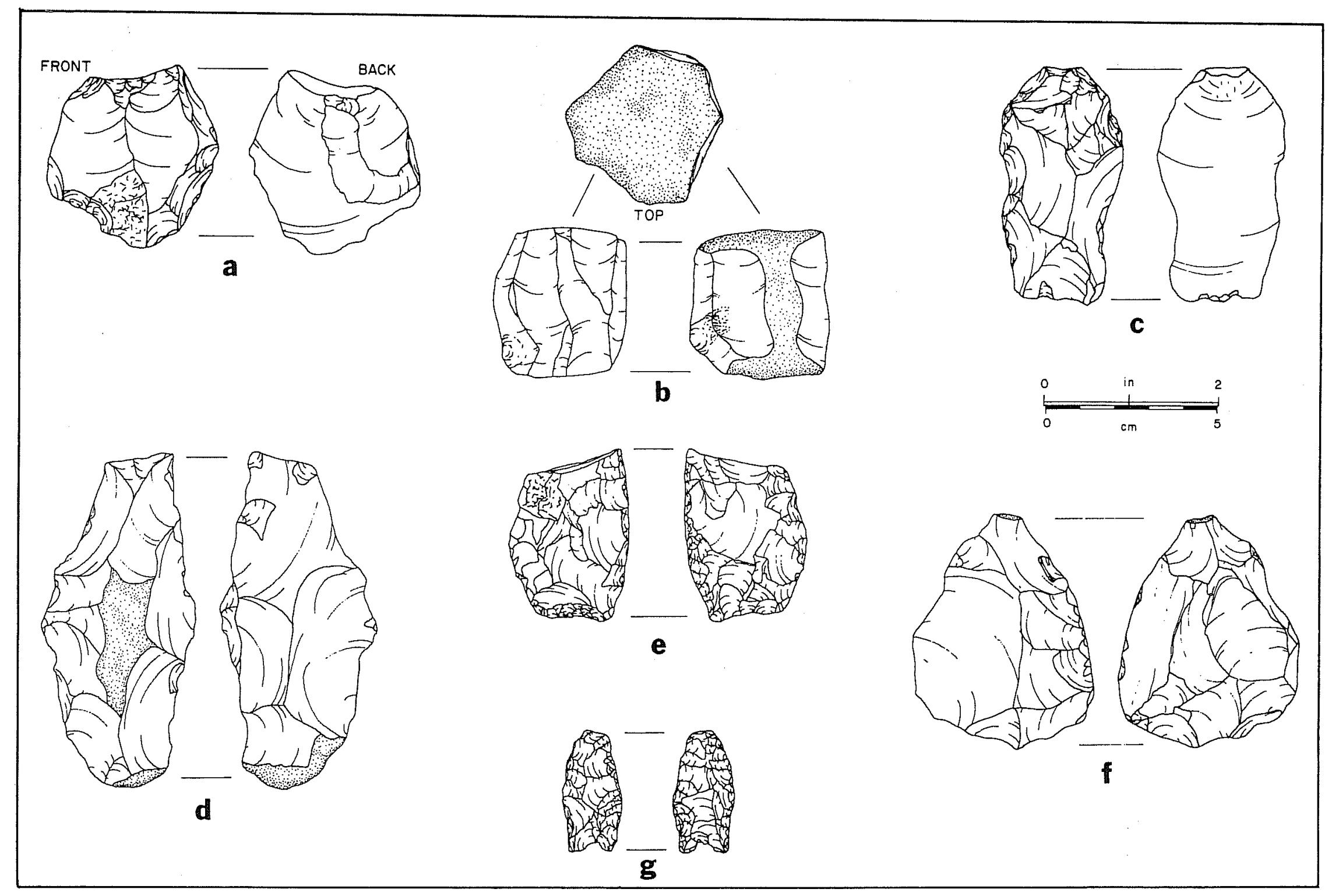

Figure 6. Artifacts from 41 FR 21. a, interior flake with heat spal1s; b, possible core altered by heavy machinery; c, bifacial thinning flake with possible retouch; d, bifacial core; e, biface with heat spalls; f, preform; g, projectile point. 
The two archaeological sites recorded in this survey cannot be placed with certainty into a specific time period. The area was probably utilized over a couple of millennium beginning in the Archaic period. However, tool assemblages and debitage for the area need to be studied in detail in hope that a chronological order may be placed upon these types of lithic quarries or workshop areas (cf. Hester 1975b; Hester and Shafer 1975; Shafer and Hester 1971; Fox 1979; and others). Hester (1980) has indicated that the prehistory of southern Texas is made up of varied cultural patterns and eventually will be integrated into regional chronological frameworks.

\section{CONCLUSIONS AND RECOMMENDATION}

The Center for Archaeological Research conducted an archaeological survey for the Medina Electric Cooperative, Inc., examining distribution lines and substations to be constructed in Uvalde, Medina, and Frio Counties in south-central and southern Texas. The proposed lines are to cross known archaeological and historical districts. The three areas involved in the survey included the D'Hanis substation line in Medina County, the Ferris substation line in Uvalde County, and the Derby substation Tine in Frio County.

Archaeological material was not observed in the proposed development areas in Medina and Uvalde Counties. In Frio County, however, two moderate 7ithic scatters were located along the Derby line. Both concentrations represent stonechipping activity carried out by aboriginal peoples. The areas were recorded and registered with the Texas Archeological Research Laboratory in Austin and officially designated as 41 FR 20 and 41 FR 21. The sites were noted to be extensively disturbed by man-made and natural forces and were judged to be limited to the surface only. Further archaeological work is not recommended for these sites. If the proposed distribution lines are to be $\mathrm{placed}$ in areas other than the areas surveyed, then any newly proposed routes would need to be examined. The possibility also remains that archaeological evidence may be unearthed during the operation. If this should happen, a qualified archaeologist should be contacted to evaluate the situation.

\section{ACKNOWLEDGMENTS}

We would like to thank Jack Eaton, Associate Director of the Center for Archaeological Research, and Dr. Thomas R. Hester, Center Director, for their advice and comments on problems relating to the project.

We would also like to thank the staff of the Medina Electric Cooperative, Inc., for their hospitality and cooperation during this project. 


\section{REFERENCES CITED}

Barry, R. G. and R. J. Chorley

1968 Atmosphere, weather and Climate. 3rd edition. Methuen and Company Ltd., Great Britain.

Benfer, A. and R. Benfer

1981 The Mason Ranch Burial Cave, Uvalde County, Texas. La Tierra $8(3): 16-26$.

Blair, W. F.

1950 The Biotic Provinces of Texas. Texas Journal of Science 1(2): $93-117$.

Brune, G.

1975 Major and Historical Springs of Texas. Texas Water Development Board, Report 189.

Carr, J. T., Jr.

1967 The Climate and Physiography of Texas. Texas water Development Board, Report 53.

Ellis, T. L., T. G. Jordan, and J. R. Buchanan

1976 Cultural and Historical Maps of Texas. From the Atlas of Texas. Bureau of Business Research, The University of Texas at Austin.

Finger, J.R.

1972 1847-1972, History of St. Dominic's Catholic Church, 01d D'Hanis, Texas. 125th Anniversary of Holy Cross Parish. Privately printed. Document on file at the Daughters of the Repubiic of Texas Library.

Fox, D. E.

1979 The Lithic Artifacts of Indians at the Spanish Colonial Missions, San Antonio, Texas. Center for Archaeological Research, The university of Texas at San Antonio, Special Report 8.

Haass, H. E.

1908 Notes and Fragments. Quarterly of the Texas State Historical Association 12(1):80-81.

Hal1, G. D.

1974 Leona River Watershed, Uvalde County, Texas: An Archeological and Historical Survey of Areas Proposed for Modifications. Texas Archeological Survey, The University of Texas at Austin, Research Report 37 . 
Hester, T. R.

1968 Paleo-Indian Artifacts from Sites along San Miguel Creek: Frio, Atascosa and McMullen Counties, Texas. Bulletin of the Texas Archeological Society 39:147-161.

1971 Archeological Investigations at the La Jita Site, Uvalde County, Texas. Bulletin of the Texas Archeological Society 42:51-148.

1975a Archaeological and Historical Resources in the San AntonioGuadalupe River Basins: A Preliminary Statement. Center for Archaeological Research. The University of Texas at San Antonio, Regional Studies 1.

1975b Chipped Stone Industries on the Rio Grande Plain, Texas: Some Preliminary Observations. Texas Journal of Science 26(1-2):213222.

1979 Notes on Gower, Jetta and Other Projectile Points of the PreArchaic Period in Texas. La Tierra 6(3):5-8.

1980 A Chronological Overview of Prehistoric Southern and SouthCentral Texas. In Papers on the Prehistory of Northeastern Mexico and Adjacent Texas, edited by J. F. Epstein, T. R. Hester, and C. Graves:119-138. Center for Archaeological Research, The University of Texas at San Antonio, Special Report 9.

Hester, T. R. and H. J. Shafer

1975 An Initial Study of Blade Technology on the Central and Southern Texas Coast. Plains Anthropologist 20(69):175-185.

Hester, T. R., R. F. Heizer, and J. A. Graham

1975 Field Methods in Archaeology. 6th edition. Mayfield Publishing Company, Palo Alto, California.

Hester, T. R. and T. C. Kelly

1976 Archaeological Investigations at Sites Near Natalia, Medina County, Texas. Center for Archaeological Research, The University of Texas at San Antonio, Archaeological Survey Report 20.

Highley, L., C. Graves, C. Land, and G. Judson

1978 Archeological Investigations at Scorpion Cave (41 ME 7), Medina County, Texas: Bulletin of the Texas Archeological Society 49: 139-198.

Hunt, C. B.

1967 Physiography of the United States. W. H. Freeman and Company, San Francisco. 
Luke, C. J.

1979 The Cook's Slough Site (41 UV 68). Texas State Department of Highways and Public Transportation, Report 15.

Patterson, W. L.

1975 A Quarry Site in Medina County, Texas. La Tierra 2(1):19-23.

Shafer, H. J.

1979 Comments on Kelly's "Gower Projectile Point?" Article. La Tierra. $6(3): 9-10$.

Shafer, H. J. and T. R. Hester

1971 A Study of the Function and Technology of Certain Bifacial Tools from Southern Texas. Texas Historical Survey Committee, Archeological Report 20.

Stevens, J. W. and D. L. Richmond

1976 Soil Survey of Uvalde County, Texas. United States Department of Agriculture, Soil Conservation Service and Texas Agricultural Experiment Station, Washington, D.C.

Tunne11, C. D. and W. W. Newcomb, Jr.

1969 A Lipan Apache Mission: San Lorenzo de 1a Santa Cruz, 17621771. Texas Memarial Museum Bulletin 14.

Webb, W. P. (Editor)

1952 Handbook of Texas; Vo1. 1. Texas State Historical Association, Austin.

Wesolowsky, A. B., T. R. Hester, and D. R. Brown

1976 Archeological Investigations at the Jetta Court Site (41 VT 151), Travis County, Texas. Bulletin of the Texas Archeological society $47: 25-81$.

Whitsett, H.

1976 Archeological Reconnaissance of Medina County, WCID 3. Report submitted to the Texas Water Quality Board.

Young, W. C.

1979 The ETm Creek Site (41 UV 67). Texas State Department of Highways and Public Transportation, Report 14. 


\section{ABSTRACT}

An archaeological survey of powerline right-of-ways was conducted in Uvalde, Medina, and Frio Counties of south Texas by the Center for Archaeological Research, The University of Texas at San Antonio. No significant cultural resources were found in the areas surveyed in Uvalde and Medina Counties. However, two prehistoric sites (41 FR 20 and 41 FR 21) were documented in the Frio County survey. The two sites are lithic scatters of little depth and will not require further work. 
